\title{
ANALISIS PROKRASTINASI TUGAS AKHIR/SKRIPSI
}

\author{
TATAN Z.M. \\ Program Studi Pendidikan Matematika, Fakultas Teknik, Matematika \& IPA \\ Universitas Indraprasta PGRI
}

\begin{abstract}
Abstrak. Penelitian ini bertujuan untuk mengetahui faktor yang menyebabkan siswa menunda menyelesaikan tugas akhir/skripsi. Penelitian ini dilaksanakan di Universitas Indraprasta PGRI, pada bulan Juni hingga Agustus 2011. Sampel penelitian sebanyak 80 orang yang diambil dari mahasiswa program studi Pendidikan Matematika yang sedang menyelesaikan skripsi. Metode yang digunakan adalah survei dengan teknik analisis dekriptif. Teknik analisis yang digunakan adalah faktor analisis dan analisis proses hirarki (AHP). Hasil yang didapat disimpulkan dalam 3 faktor dominan yang menyebabkan mahasiswa menunda menyelesaikan skripsi, 1) $83,8 \%$ mahasiswa memiliki keterbatasan dalam pemahaman tentang membuat skripsi, 2) $82,6 \%$ mahasiswa memiliki keterbatasan pemahaman tentang metode penelitian, dan 3) $76,3^{\wedge}$ mahasiswa memiliki keterbatasan tentang mata kuliah seminar pra skripsi.
\end{abstract}

Kata Kunci: prokrastinasi, skripsi, analisis faktor, AHP

\begin{abstract}
This research aim to to know factors causing student procrastinate in solving of theses/final duty. Research location in University of Indraprasta PGRI Jakarta. Time Research executed in June - August 2011. Research Sampel counted 80 student of Education of Mathematics Program which is finishing theses. Method which is used in this research is method of survey with technique of deksirptif. Technique analyse used data cover; factor analysis and analysis of hirerarchi process (AHP). Result of factor analysis conclude that there is 3 dominant factor which cause postponement of student in finishing of skripsi; 1) $83.8 \%$ student less is comprehending is way of making of theses, 2) $82.6 \%$ student less is comprehending of eye of study research method, 3) $76.3 \%$ student less is comprehending of eye of studi pre seminar of theses.
\end{abstract}

Keywords: procrastinate, theses, factor analysis, AHP.

\section{PENDAHULUAN}

Burka dan Yuen mengemukakan bahwa prokrastinasi terjadi pada setiap individu tanpa memandang usia, jenis kelamin, atau statusnya sebagai pekerja atau pelajar. William dalam Burka dan Yuen memperkirakan bahwa 90\% mahasiswa dari perguruan tinggi telah menjadi seorang prokrastinator, $25 \%$ adalah orang suka menunda nunda kronis dan mereka adalah pada umumnya berakhir mundur dari perguruan tinggi. (Tondok, 2008)

Solomon dan Rothblum melakukan penelitian di salah satu Universitas di Amerika Serikat dengan jumlah subjek sebanyak 322 orang. Data prokrastinasi tugas akademik terungkap bahwa $46 \%$ subjek penelitian melakukan prokrastinasi dalam mengerjakan tugas. (Tondok, 2008)

Rizvi, melakukan penelitian mengenai prokrastinasi akademik ditinjau dari pusat kendali dan efikasi diri pada 111 Mahasiswa Psikologi Universitas Gadjah Mada Yogyakarta. Hasil menunjukkan bahwa 20,38\% mahasiswa telah melakukan prokrastinasi akademik dan didapat hubungan positif antara prokrastinasi akademik dengan pusat kendali eksternal. (Rizvi,1997 : 60) 
Solomon dan Rothblum dalam Rumiani mengungkapkan bahwa indikasi penundaan akademik adalah masa studi 5 tahun atau lebih. Menurut data Informasi Mahasiswa dan Lulusan yang diperoleh dari Biro Administrasi Perencanaan dan Sistem Informasi (BAPSI) Universitas Diponegoro Semarang, pada jenjang program S-1 bahwa lulusan Psikologi dari tahun ajaran 2002/2003 sampai tahun ajaran 2004/2005 diketahui lama studi rata-rata adalah 6 tahun 1 bulan, 5 tahun 10 bulan, dan 5 tahun 11 bulan. Kondisi demikian menjadikan mahasiswa fakultas psikologi dapat dikatakan sebagai prokrastinator akademik. (Tondok, 2008)

Penelitian Catrunada menyatakan bahwa, $40 \%$ hambatan yang mereka rasakan saat menyusun skripsi adalah mengalami kesulitan untuk konsentrasi dengan tugas skripsi. Hal ini bisa dikarenakan adanya hal-hal lain yang memecah konsentrasi seseorang apakah karena telah bekerja, telah berkeluarga, atau karena situasi lingkungan yang tidak mendukung dalam menyelesaikan skripsi sehingga subjek tersebut melakukan penundaan. Sedangkan hambatan paling rendah yang dirasakan oleh subjek penelitian adalah adanya daya tahan tubuh yang menurun sebesar $13,33 \%$. (Catrunada, 2005)

Solomon dan Rothblum dalam Tuckman mengemukakan bahwa prokrastinasi adalah suatu kecenderungan untuk menunda dalam memulai maupun menyelesaikan kinerja secara keseluruhan untuk melakukan aktivitas lain yang tidak berguna, sehingga kinerja menjadi terhambat, tidak pernah menyelesaikan tugas tepat waktu, serta sering terlambat dalam perkuliahan. Ellis dan Knaus dalam Rumiani menemukan bahwa hampir 70\% mahasiswa melakukan prokrastinasi. (Tondok, 2008)

\section{TINJAUAN PUSTAKA}

\section{Prokrastinasi Tugas Akhir}

Fiore (2006: 56) mengatakan bahwa secara etiologis atau menurut asal katanya, istilah prokrastinasi berasal dari bahasa latin yaitu pro atau forward yang berarti maju, dan crastinus atau tomorrow yaitu hari esok, ini berarti prokrastinasi adalah maju pada hari esok. Sedangkan secara etimologis prokrastinasi adalah suatu mekanisme untuk mengatasi kecemasan yang berhubungan dengan bagaimana cara memulai atau melengkapi suatu pekerjaan dan dalam hal membuat keputusan.

Menurut Ferrari, bentuk-bentuk prokrastinasi ada dua yaitu: (a) Prokrastinasi Fungsional (Functional Procrastination), dan (b) Prokrastinasi Disfungsional (Disfunctional Procrastination) (Tondok, 2008)

Sementara itu, menurut Schouwenburg dalam Ferrari menyatakan bahwa indikator prokrastinasi akademik adalah sebagai berikut : (a) Penundaan pelaksanaan tugastugas akademik, (b) Kelambanan dan keterlambatan dalam mengerjakan tugas akademik, (c) Ketidaksesuaian antara rencana dengan performansi aktual, dan (d) Melakukan aktivitas lain yang lebih menyenangkan. (Tondok, 2008)

Friend dalam Timpe berpendapat bahwa prokrastinasi dipengaruhi faktor-faktor sebagai berikut: (a) Tidak yakin diri, (b) Toleransi frustrasi yang rendah, (c) Menuntut kesempurnaan, (d) Perbedaan jenis kelamin, dan (e) Pandangan fatalistik. (Timpe, 2000)

Senada dengan pendapat di atas, Braid dalam Timpe juga mengemukakan bahwa prokrastinasi dapat dipengaruhi faktor-faktor sebagai berikut: (a) Kerumitan, (b) Ketakutan. (Timpe, 2000)

Menurut Burka dan Yuen, terbentuknya tingkah laku prokrastinasi dipengaruhi oleh faktor-faktor antara lain : kecemasan terhadap evaluasi yang akan diberikan, kesulitan dalam mengambil keputusan, pemberontakan terhadap kontrol dari figur otoritas, kurangnya tuntutan dari tugas, standar yang terlalu tinggi mengenai kemampuan individu. (Tondok, 2008) 
Sementara itu, Catrunada mengungkapkan tentang sepuluh wilayah magnetis yang menjadi faktor-faktor dilakukannya prokrastinasi:

a) Anxiety

Anxiety dapat diartikan sebagai kecemasan.. Kecemasan pada akhirnya menjadi kekuatan magnetik yang berlawanan dimana tugas-tugas yang diharapkan dapat diselesaikan berinteraksi dengan kecemasan yang tinggi, sehingga seseorang cenderung menunda tugas tersebut.

b) Self-Depreciation

Dapat diartikan sebagai pencelaan terhadap diri sendiri. Seseorang memiliki penghargaan yang rendah atas dirinya sendiri dan selalu siap untuk menyalahkan diri sendiri ketika terjadi kesalahan dan juga merasa tidak percaya diri untuk mendapat masa depan yang cerah.

c) Low Discomfort Tolerance

Dapat diartikan sebagai rendahnya toleransi terhadap ketidaknyamanan. Adanya kesulitan pada tugas yang dikerjakan membuat seseorang mengalami kesulitan untuk menoleransi rasa frustrasi dan kecemasan, sehingga mereka mengalihkan diri sendiri kepada tugas-tugas yang mengurangi ketidaknyamanan dalam diri mereka.

d) Pleasure-seeking

Dapat diartikan sebagai pencari kesenangan. Seseorang yang mencari kenyamanan cenderung tidak mau melepaskan situasi yang membuat nyaman tersebut. Jika seseorang memiliki kecenderungan tinggi dalam mencari situasi yang nyaman, maka orang tersebut akan memiliki hasrat kuat untuk bersenang-senang dan memiliki kontrol impuls yang rendah.

e) Time Disorganization

Dapat diartikan sebagai tidak teraturnya waktu. Mengatur waktu berarti bisa memperkirakan dengan baik berapa lama seseorang membutuhkan waktu untuk menyelesaikan pekerjaan tersebut. Aspek lain dari lemahnya pengaturan waktu adalah sulitnya seseorang memutuskan pekerjaan apa yang penting dan kurang penting untuk dikerjakan hari ini. Semua pekerjaan terlihat sangat penting sehingga muncul kesulitan untuk menentukan apa yang harus dikerjakan terlebih dahulu.

f) Environmental Disorganisation

Dapat diartikan sebagai berantakan atau tidak teraturnya lingkungan. Salah satu faktor prokrastinasi adalah kenyataan bahwa lingkungan disekitarnya berantakan atau tidak teratur dengan baik, hal itu terjadi kemungkinan karena kesalahan individu tersebut. Tidak teraturnya lingkungan bisa dalam bentuk interupsi dari orang lain, kurangnya privasi, kertas yang bertebaran dimana-mana, dan alat-alat yang dibutuhkan dalam pekerjaan tersebut tidak tersedia. Adanya begitu banyak gangguan pada area wilayah pekerjaan menyulitkan seseorang untuk berkonsentrasi sehingga pekerjaan tersebut tidak bisa selesai tepat pada waktunya.

g) Poor Task Approach

Dapat diartikan sebagai pendekatan yang lemah terhadap tugas. Jika akhirnya seseorang merasa siap untuk bekerja, kemungkinan dia akan meletakkan kembali pekerjaan tersebut karena tidak tahu darimana harus memulai sehingga cenderung menjadi tertahan oleh ketidaktahuan tentang bagaimana harus memulai dan menyelesaikan pekerjaan tersebut.

h) Lack of Assertion

Dapat diartikan sebagai kurangnya memberikan pernyataan yang tegas. Contohnya adalah seseorang yang mengalami kesulitan untuk berkata tidak terhadap permintaan yang ditujukan kepadanya sedangkan banyak hal yang harus dikerjakan karena telah 
dijadwalkan terlebih dulu. Hal ini bisa terjadi karena mereka kurang memberikan kehormatan atas semua komitmen dan tanggung jawab yang dimiliki.

i) Hostility with others

Dapat diartikan sebagai permusuhan terhadap orang lain. Kemarahan yang terus menerus bisa menimbulkan dendam dan sikap bermusuhan sehingga bisa menuju sikap menolak atau menentang apapun yang dikatakan oleh orang tersebut.

j) Stress and fatigue

Dapat diartikan sebagai perasaan tertekan dan kelelahan.. Stres adalah hasil dari sejumlah intensitas tuntutan negatif dalam hidup yang digabung dengan gaya hidup dan kemampuan mengatasi masalah pada diri individu. Semakin banyak tuntutan dan semakin lemah sikap seseorang dalam memecahkan masalah, dan gaya hidup yang kurang baik, semakin tinggi stres seseorang (Catrunada, 2005)

Berdasarkan teori-teori di atas, yang dimaksud prokrastinasi dalam penelitian ini adalah penundaan yang dilakukan secara sengaja dan berulang-ulang dalam menyelesaikan suatu tugas atau pekerjaan, baik memulai maupun menyelesaikan tugas yang berhubungan dengan bidang akademik, yang ditandai dengan 2 dimensi, yaitu: 1 . faktor internal dengan indikator: 1) kecemasan, 2) tanggung jawab, 3) tekanan dan kelelahan, 4) ketidakmampuan; 2. faktor eksternal dengan indikator, 1) tidak teraturnya waktu, 2) tidak teraturnya lingkungan, 3) permusuhan terhadap orang lain, 4) bimbingan

\section{Pengertian Skripsi/Tugas Akhir}

Menurut Wirartha, skripsi adalah karya tulis ilmiah seorang mahasiswa dalam menyelesaikan program S1. Skripsi tersebut adalah bukti kemampuan akademik mahasiswa bersangkutan dalam penelitian dengan topik yang sesuai dengan bidang studinya. Skripsi disusun dan dipertahankan untuk mencapai gelar sarjana strata satu. Biasanya, skripsi menjadi salah satu syarat kelulusan. (Wirartha, 2006: 45)

Sementara itu, dalam buku panduan penulisan skripsi/tugas akhir Unindra dikatakan: "Skripsi adalah suatu karya ilmiah yang disusun oelh seorang mahasiswa berdasarkan hasil penelitian dengan menggunakan data primer atau data sekunder yang penulisannya terikat pada sistematika formal dan tunduk pada asas logika ilmiah serta metodologi yang benar" (Panduan Skripsi Unindra, 2004 : 1)

Pendapat senada dikatakan pula bahwa skripsi adalah suatu karya tulis ilmiah berupa paparan tulisan hasil penelitian yang membahas suatu masalah dalam bidang ilmu tertentu dengan menggunakan kaidah-kaidah yang berlaku dalam suatu bidang ilmu. Skripsi merupakan karya tulis ilmiah yang wajib dikerjakan oleh setiap mahasiswa yang mengambil jenjang program studi strata satu (S-1), sebagai tugas akhir dalam studi mereka. Skripsi juga merupakan sebuah bukti yang menunjukkan kemampuan akademik mahasiswa yang bersangkutan dalam penelitian yang berhubungan dengan masalah pendidikan sesuai dengan bidang studinya. (http://fisip.ub.ac.id/webfisub, diakses tanggal 10 maret 2011)

Berdasarkan teori-teori di atas, yang dimaksud skripsi dalam penelitian ini adalah suatu karya ilmiah yang disusun oleh seorang mahasiswa berdasarkan hasil penelitian dengan menggunakan data primer atau data sekunder yang penulisannya terikat pada sistematika formal dan tunduk pada asas logika ilmiah serta metodologi yang benar.

Dari dua pengertian di atas, dapat disimpulkan bahwa prokrastinasi skripsi dalam penelitian ini adalah penundaan yang dilakukan secara sengaja dan berulang-ulang dalam menyelesaikan suatu tugas atau pekerjaan, baik memulai maupun menyelesaikan tugas yang berhubungan dengan skripsi/tugas akhir 
Beberapa penelitian yang membahas tentang prokrastinasi skripsi/tugas akhir:

1. William dalam Burka dan Yuen, memperkirakan bahwa $90 \%$ mahasiswa dari perguruan tinggi telah menjadi seorang prokrastinator, $25 \%$ adalah orang suka menunda nunda kronis dan mereka adalah pada umumnya berakhir mundur dari perguruan tinggi.

2. Solomon dan Rothblum, melakukan penelitian di salah satu Universitas di Amerika Serikat dengan jumlah subjek sebanyak 322 orang. Data prokrastinasi tugas akademik terungkap bahwa $46 \%$ subjek penelitian melakukan prokrastinasi dalam mengerjakan tugas.

3. Rizvi, juga melakukan penelitian mengenai prokrastinasi akademik ditinjau dari pusat kendali dan efikasi diri pada 111 Mahasiswa Psikologi Universitas Gadjah Mada Yogyakarta. Hasil menunjukkan bahwa 20,38\% mahasiswa telah melakukan prokrastinasi akademik dan didapat hubungan positif antara prokrastinasi akademik dengan pusat kendali eksternal.

4. Lidya Catrunada, menyatakan bahwa, $40 \%$ hambatan yang mereka rasakan saat menyusun skripsi adalah mengalami kesulitan untuk konsentrasi dengan tugas skripsi. Hal ini bisa dikarenakan adanya hal-hal lain yang memecah konsentrasi seseorang apakah karena telah bekerja, telah berkeluarga, atau karena situasi lingkungan yang tidak mendukung dalam menyelesaikan skripsi sehingga subjek tersebut melakukan penundaan. Sedangkan hambatan paling rendah yang dirasakan oleh subjek penelitian adalah adanya daya tahan tubuh yang menurun sebesar 13,33 $\%$.

5. Rumiani dalam sebuah penelitiannya, faktor motivasi berprestasi memiliki korelasi dengan prokrastinasi akademik. Stres mahasiswa tidak memiliki korelasi dengan prokrastinasi akademik. Ini berarti bahwa pada subyek penelitian ini, prokrastinasi banyak dipengaruhi oleh faktor internal (motivasi berprestasi).

\section{METODE}

Penelitian ini dilaksanakan di FTMIPA Universitas Indraprasta PGRI Jakarta Program Studi Pendidikan Matematika. Waktu penelitian berlangsung selama 3 bulan, yaitu mulai bulan Juni - Agustus 2011. Metode penelitian yang dipakai adalah metode survey dengan teknik deskriptif. Sampel dalam penelitian ini sebanyak 80 mahasiswa Universitas Indaprasta PGRI Jakarta Program Studi Pendidikan Matematika yang sedang menyusun skripsi. Instrumen yang digunakan untuk penyaringan data adalah kuesioner yang terdiri 15 butir penyataan.Pengujian intrumen penelitian dilakukan dengan internal validity. Teknik analisis data yang digunakan meliputi; analisis deskriptif, analisis faktor dan analisis hirerarchi process (AHP).

\section{HASIL DAN PEMBAHASAN}

\section{Analisis Deskripstif}

a. Perasaan pada saat mengambil mata kuliah skripsi

Saat mengambil mata kuliah skripsi, perasaan mahasiswa berada pada tingkat kecemasan yang rendah, yaitu adanya perasaan mendekati rasa takut pada saat mengambil mata kuliah skripsi dengan tingkat rata-rata 37,5\% (perasaan biasa) dan $32,5 \%$ (perasaan takut).

b. Penyebab rasa takut mengambil mata kuliah skripsi

Penyebab rasa takut mengambil mata kuliah skripsi, ketidakpahaman mahasiswa pada saat mengambil skripsi cukup tinggi, yaitu 78,8 \% mahasiswa tidak paham dalam pembuatan skripsi 
c. Kesamaan judul skripsi pada saat mengambil mata kuliah seminar pra skripsi

Kesamaan judul skripsi pada saat mengambil mata kuliah seminar pra skripsi dengan pada saat penyusunan skripsi cukup baik, yaitu $41,3 \%$ judul skripsi sama dengan judul pada saat seminar skripsi

d. Memahami dan mengerti mata kuliah metode penelitian

Mahasiswa memahami dan mengerti mata kuliah metode penelitian cukup rendah, yaitu $28,8 \%$ pemahaman mahasiswa dalam metode penelitian

e. Memahami dan mengerti mata kuliah statistik

Mahasiswa memahami dan mengerti mata kuliah statistik cukup rendah, yaitu $40 \%$ pemahaman mahasiswa dalam mata kuliah statistik

f. Memahami dan mengerti mata kuliah seminar pra skripsi

Mahasiswa memahami dan mengerti mata kuliah seminar pra skripsi cukup rendah, yaitu $38,8 \%$ mahasiswa yang memahami mata kuliah seminar pra skripsi

g. Memahami cara pembuatan skripsi

Mahasiswa memahami dan mengerti cara pembuatan skripsi cukup, yaitu 53,8\% mahasiswa mengetahui cara pembuatan skripsi

h. Berkonsultasi dengan pembimbing

Intensitas konsultasi dengan pembimbing kurang baik, yaitu $40 \%$ mahasiswa jarang berkonsultasi dengan pembimbing

i. Pembimbing memberikan bimbingan dengan baik dan jelas

Pembimbing memberikan bimbingan dengan baik dan jelas sangat baik, yaitu 76,3\% mahasiswa mendapatkan bimbingan dengan baik dan jelas dari pembimbim skripsi

j. Intensitas Bimbingan Skripsi

Intensitas bimbingan skripsi cukup baik, yaitu 58,8 \% mahasiswa mengadakan bimbingan dengan dosen 1-2 kali dalam 1 bulan

k. Penyebab mahasiswa malas dalam bimbingan skripsi

Penyebab mahasiswa malas dalam bimbingan skripsi $40 \%$ disebabkan oleh kelelahan mahasiswa dalam menghadapi pembuatan skripsi

1. Kepemilikan buku panduan penulisan skripsi yang dikeluarkan oleh Unindra

Kepemilikan buku panduan penulisan skripsi yang dikeluarkan oleh Unindra sangat baik, $88,8 \%$ para mahasiswa memiliki buku panduan penulisan skripsi yang dikeluarkan oleh Unindra

m. Membaca buku panduan skripsi dengan baik

Membaca buku panduan skripsi dengan baik sangat baik, $50 \%$ para mahasiswa membaca buku panduan skripsi dengan baik

n. Peranan buku panduan skripsi

Peranan buku panduan skripsi kurang memadai, 52,5\% mahasiswa menganggap buku panduan skripsi yang dikeluarkan Unindra kurang memadai

o. Bab dalam penulisan skripsi yang kurang dipahami

Bab dalam penulisan skripsi yang kurang dipahami adalah bab 3 dan bab 4, $85 \%$ mahasiswa menganggap bab 4 dan 5 kurang menguasai.

\section{Analisis Faktor}

Hasil analisis faktor menyimpulkan bahwa ada 3 faktor dominan yang menyebabkan penundaan mahasiswa dalam penyelesian skripsi; 1) 83,8\% mahasiswa kurang memahami cara pembuatan skripsi, 2) 82,6\% mahasiswa kurang memahami mata kuliah metode penelitian, 3) 76,3\% mahasiswa kurang memahami mata kuliah seminar pra skripsi. 


\section{Analisis Hierarchis Prosess (AHP)}

Hasil pengujian analisis hirerarchi process (AHP) menyimpulkan bahwa 3 faktor dominan yang menyebabkan penundaan mahasiswa dalam penyelesaian skripsi; 1) kesulitan mahasiswa dalam pembuatan skripsi terutama yang berkaitan dengan statistik, 2) kesulitan mahasiswa dalam penyelesain bab 3 dan bab 4, 3) kesulitan mahasiswa dalam metode penelitian.

\section{Pembahasan}

Tidak dipungkiri bahwa akhir dari sebuah proses pembelajaran di tingkat perguruan tinggi adalah penyelesaian tugas akhir atau untuk tingkat S1 dikenal dengan skripsi. Artinya, kegiatan pembelajaran di tingkat perguruan tinggi belum dikatakan selesai atau lulus apabila tugas akhir/skripsinya belum selesai. Bahkan tidak jarang, mahasiswa yang gagal akibat tugas akhir/skripsinya tidak selesai.

Kejadian gagalnya mahasiswa karena tidak dapat menyelesaikan tugas akhir/skripsinya merupakan fenomena yang sering terjadi hampir di semua perguruan tinggi. Fenomena tersebut dikenal dengan sebutan prokrastinasi tugas akhir/skripsi.

Prokrastinasi skripsi merupakn proses penundaan yang dilakukan secara sengaja dan berulang-ulang dalam menyelesaikan suatu tugas atau pekerjaan, baik memulai maupun menyelesaikan tugas yang berhubungan dengan skripsi/tugas akhir.

Hasil analisis yang dilakukan peneliti menemukan beberapa faktor yang menyebabkan sesorang menunda-nunda tugas akhir/skripsinya, diantaranya:

Pertama, hasil analisis faktor menyimpulkan bahwa ada 3 faktor dominan yang menyebabkan penundaan mahasiswa dalam penyelesian skripsi; 1) $83,8 \%$ mahasiswa kurang memahami cara pembuatan skripsi, 2) 82,6\% mahasiswa kurang memahami mata kuliah metode penelitian, 3) 76,3\% mahasiswa kurang memahami mata kulaih seminar pra skripsi.

Kedua, hasil analisis hirerarchi process (AHP) menyimpulkan bahwa 3 faktor dominan yang menyebabkan penundaan mahasiswa dalam penyelesaian skripsi; 1) kesulitan mahasiswa dalam pembuatan skripsi terutama yang berkaitan dengan statistik, 2) kesulitan mahasiswa dalam penyelesain bab 3 dan bab 4, 3) kesulitan mahasiswa dalam metode penelitian.

Dari dua analisis tersebut, bila digeneralisasikan bisa disebutkan bahwa faktorfaktor yang menyebabkan terjadinya prokrastinasi tugas akhir/skripsi adalah dikarenakan mahasiswa kurang memahami teknik pembuatan skripsi, kurang memahami metode penelitian dan statistik.

Hasil penelitian ini memperkuat dari penelitian-penelitian sebelumnya yang menyatakan bahwa hampir di semua perguruan tinggi telah terjadi penundaan mahasiswa terhadap penyelesaian tugas akhir/skripsi yang disebabakan oleh berbagai faktor yang ada seperti yang disebutkan dalam penelitian ini.

\section{PENUTUP}

Banyak faktor yang menyebabkan terjadinya penundaan (prokrastinasi) mahasiswa dalam menyelesaikan skripsi/tugas akhir. Dari 15 pernyataan yang dibuat oleh peneliti, ternyata ada 6 faktor dominan yang menyebabkan mahasiswa menunda-nunda skripsi/tugas akhir, yaitu: 1) pemahaman skripsi, 2) peranan buku panduan skripsi, 3) kecemasan, 4) penguasaan statistik, 5) layanan bimbingan, 6) intensitas bimbingan.

Sebagai saran perlunya penguatan terhadap peningkatan pemahaman mahasiswa tentang penyelesaian skripsi/tugas akhir terutama dalam mata kuliah metodologi penelitian dan seminar skripsi. Perlunya peningkatan buku panduan penulisan 
skripsi/tugas akhir yang lebih ditail dan lengkap agar para mahasiswa memperoleh gambaran yang lebih mudah dan memadai.

\section{DAFTAR PUSTAKA}

Catrunada, Lidya, Puspitawati, Ira, http://en.wikipedia.org/wiki/procrastination, diakses pada tanggal 10 Maret 2011

Fiore, N.A. 2006. The now habit: A strategic program for overcoming procrastination an enjoying guilt free play. New York: (http://en.wikipedia.org/wiki/procrastination, diakses pada tanggal 10 Maret 2011)

Rivzi, A., Prawitasari, J.E., Soetjipto, H.P. 1997. Pusat Kendali Dan Efikasi Diri Sebagai Prediktor Prokastinasi Akademik Mahasiswa. Psikologika. No.3,Tahun II

Rumiani. 2006. Prokrastinasi Akademik Ditinjau dari Motivasi Berprestasi dan Stres Mahasiswa. Jurnal Psikologi Universitas Diponegoro Semarang Vol.3, No. 2.

Timpe, A. D. 2000. Mengelola Waktu: Seri Manajemen Sumber Daya Manusia. Jakarta: PT. Elex Media Komputindo.

Tondok, Marselius Sampe et al. Anima Indonesian Psycological Journal 2008, Vol 24 No 1, diakses tanggal 10 Maret 2011 ,http://fisip.ub.ac.id/webfisub/attachments/buku/buku\%20pedoman\%20peny usunan\%20skripsi\%202010.pdf . diakses tanggal 10 maret 2011

Wirartha, I.M. 2006. Pedoman Penulisan Usulan Penelitian, Skripsi, Dan Tesis. Yogyakarta: Andi Offset 